\title{
PROSPECTS FOR THE EXPANSION OF THE WORLD MARKER FOR DESICCATED COCONUT
}

\author{
by \\ G.A. HONE, A.D. JOHNSON, A.D. MARTER and W.H. TIMMINS ${ }^{1}$
}

\begin{abstract}
The world market for desiccated coconut (DC) is examined within a supply and demand framework. Production and marketing arrangements within DC producing countries are analysed, in addition to consumption trends in the major DC markets of Europe and North America. The prospects for expanding the DC market are then considered, and some potential is found in amas such as: research and development, product promotion and-markethig strategy.
\end{abstract}

\section{Introduction}

APCC member countries supply over $90 \%$ of the global trade in desiccated coconut (DC). Almost all DC production originates from just four countries : the Philippines, Sri Lanka, Malaysia arsd Indonesia. The major importing countries are in North America and Western Europe, although FAO trade data show that markets for DC exist in almost every country. The world market for DC has grown by about $30 \%$ over the last two decades, although it has shown little growth in the most recent of these years. DC prices have tended to shadow those of coconut oil, and have halved in real terms since the mid-1980s. DC prices are currently around US\$900/tonne c\&f.

\section{The supply of Desiccated coconut}

The Philippines is the major producer of DC and accounts for over half of total world exports (see Table 1 and Chart 1). The second largest producer is Sri Lanka, which currently supplies approximately one third of the world export market. Twenty years ago, the Philippine market share was not much greater than that held by Sri Lanka. However, since this period the DC industry in the Philippines has shown stronger growth than that in Sri Lanka, with Philippine exports well up on the level of the 1960s, while Sri Lankan exports have fallen. The Philippine industry has been able successfully to use aggressive and organised marketing strategies to facilitate export growth, while Sri Lankan exports stagnated. However, the Sri Lankan industry has shown signs of recovery since the low point of the late 1970s, with exports reaching almost 60,000 tonnes in 1986.

Table 1. Exports of DC by the major APCC producing countries 1966 - 1989 (annual averages in MT wer 3 year periods)

\begin{tabular}{l|r|r|r|}
\hline \multicolumn{1}{|c|}{ Year } & $1968 / 70$ & $1978 / 80$ & $1988 / 90$ \\
\hline Philippines & 62,000 & 87,600 & 85,700 \\
Sri Lanka & 57,000 & 37,800 & 38,700 \\
Malaysia & - & 1,000 & 20,700 \\
Indonesia & - & 900 & 2,400 \\
Cote d'Ivoire & 600 & - & 6,500 \\
Total - main suppliers & 119,600 & 127,300 & 154,000 \\
\hline
\end{tabular}

\footnotetext{
${ }^{1}$ Natural Resources Institute, London, England.
} 
The most significant change in output over the past ten years has occurred in Malaysia, which has increased shipments from negligible levels in the mid-1970s, to a point where it now exports around 20,000 tonnes per year.

The Indonesian DC industry, which was established before its Malaysian counterpart, has failed to make as great an impact on world trade as more recent entrants. The Indonesian industry was hampered in its early years by a variety of problems including variable DC quality and logistical difficulties related to inter-island transport and the need for trans-shipment. Indonesian exports are currently between 2,000 and 3,000 tonnes per year. Nevertheless, recent assessments from trade sources suggest that new DC plants and improvements in the quality of Indonesian DC are beginning to have an impact. Consequently, Indonesian exports may begin to displace those of the traditional suppliers.

Outside Asia, the Cote d'lvoire is the only significant source of DC, exporting around 6,500 tonnes per year between 1988 and 1990. DC from the Cote d'lvoire is favoured by certain European importers.

Philippine exports of DC have averaged around 80,000 tonnes per year over the last decade, with two notable falls in the mid-1980s and in 1990 because of the effects of cyclone and drought. Table. 2 shows Philippine DC exports in 1989 and 1990, by country. The USA is the major destination for Philippine DC exports, accounting for over 40\% of total exports in 1989 and 1990. The EC is also a significant importer of the Philippine product, taking 26,000 tonnes in 1989 (28\%) and 16,000 tonnes in 1990 (22\%). Around 30\% of exports are destined for countries outside the EC or USA, such as Australia, Canada, Taiwan, Japan and Sweden. These non-EEC/USA exports reached 29,000 tonnes in 1989 and 25,000 tonnes in 1990.

Table 2. Philippine DC Exports by Destination: 1989 \& 1990 (metric tonnes)

\begin{tabular}{|l|r|r|}
\hline \multicolumn{1}{|c|}{ Year } & 1989 & 1990 \\
\hline Australia & 9,167 & 7,664 \\
Belgium/Lux &, 587 & 1,010 \\
Canada & 4,991 & 5,618 \\
Germany & 9,044 & 3,028 \\
Japan & 1,198 & 1,509 \\
Netherlands & 9,445 & 6,998 \\
Sweden & 1,432 & 1,168 \\
Taiwan & 1,481 & 1,917 \\
U K & 6,713 & 4,880 \\
USA & 38,578 & 34,054 \\
Others & 11,096 & 6,837 \\
& 93,732 & 74,683 \\
\hline
\end{tabular}

Source: United Coconut Association of the Philippines

\section{The Philippines}

Although the largest in the world, the Philippine DC industry uses only a small proportion of the total nut availability in the country, probably accounting for less than 1 in 20 of all the coconuts used (see Table 3). Furthermore, domestic consumption of coconuts - that is, all edible applications 
including the production of domestically produced oil - is similarly small. Overall, this ease of raw material availability and the absence of pressing domestic consumption needs, has been reflected in the establishment of relatively large-scale processing facilities in the Philippines. This trend was reinforced by the roles played by foreign interests in the past and by political intervention. There are proposals to deregulate the Philippine DC industry. This has reopened the possibility of increasing the number of plants operating.

Table 3. Production and utilisation of coconuts in major APCC Desiccated Coconut producing countries

\begin{tabular}{|l|r|r|r|r|}
\hline \multirow{2}{*}{ Country } & \multirow{2}{*}{$\begin{array}{c}\text { Coconut Prodn. } \\
\text { (millions) }\end{array}$} & Fresh Nuts & \multicolumn{2}{|c|}{ \% of total used for: } \\
\cline { 3 - 5 } & 11,420 & 8 & Copra & DC \\
\hline Philippines & 2,763 & 52 & 38 & 5 \\
Sri Lanka & 977 & 32 & 62 & 14 \\
Malaysia & 9,850 & 43 & 59 & 7 \\
Indonesia & & & $*$ \\
\hline
\end{tabular}

Source: derived from APCC data

Notes: *indicates negligible

Figures are rounded to nearest whole number "Fresh nuts includes all edible applications including, direct production of oil from fresh nuts (eg. klentik oil). These data are often of limited reliability.

\section{Sri Lanka}

In Sri Lanka, domestic fresh nut consumption probably accounts for more than half of total coconut utilisation. This represents a priority that must be met over and above other uses. The DC industry is therefore exposed to any instability in total nut output. Normal climatic conditions impose a seasonal cycle on DC production - droughts, hurricanes and the like are even more disruptive. These constraints on coconut availability are reflected in the structure of the Sri Lankan industry, which is largely made up of a relatively large number of small-scale plants. There are indications that some rationalisation of production capacity is occurring, with the commissioning of a few medium size plants.

\section{Malaysia}

The Malaysian DC industry is not well documented. However, it appears that it faces at least some of the same supply constraints as Sri Lanka. Overall production is relatively small and it seems unlikely that pressures from meeting domestic dernand are as large as those faced by Sri Lanka.

\section{Profitability and the expansion of capacity}

Both constraints on coconut availability and labour costs have constrained profits amongst manufacturers in recent years. Profits have also been cut as a consequence of low international prices which have arisen as a result of expanding DC availability against limited growth in demand.

Despite limits to profitability there, are substantial increases in capacity coming on strearn in most of the major producing countries. It is estimated that these investments could amount to around 25,000 tonnes capacity in total. If the new capacity is fully used, and if there are no reductions in capacity elsewhere, there would be a severely depressing effect on international prices for DC. 


\section{Marketing arrangements in the producing countries}

The structure of production has had a strong influence on the development of marketing channels for DC. Large scale production in via containerisation. the Philippines has lent itself to easy bulk handliq. The handling of DC trade is further simplified by historical links with manufacturers in the United States.

The marketing chain in Sri Lanka is usually far mor complex. The small scale of many producers, means that they may lack liquidity and often have to rely on brokers to finance raw material purchases. Brokers, are also involved in the handling of DC sales, since small parcels of output from producers have to be bulked up before export. Frequently, container loads have to be made up of mixed mill consignments and this clearly has an impact on product uniformity.

The problem of mixed-mill consignments is exacerbated by a number of factors including the competition for DC supplies from shippers. Another problern for quality control relates to the scale of operation at the mills. The smaller DC mills in Sri Lanka are unable to provide container quantities from their daily production, in contrast to the large scale operations in the Philippines. Thus, in addition to mixedmill consignments, there are also mixed-production consignments from the smaller mills.

The relative instability of production in Sri Lanka which results from limited coconut availability and seasonality has attracted speculative activity and this has further complicated the marketing systern.

Lengthy market chains impair communication of users needs and quality requirements to suppliers, especially in the case of smaller DC manufacturers. These difficulties have not yet been addressed by institutions set up to represent the interests of the coconut sector.

\section{The demand for Desiccated coconut}

The main DC importers are surnmarised in Table 4 which shows DC imports by country between 1987 and 1990. DC Imports for five countries over the period 1975 - 1990 are shown in Chart 2.

Table 4. Imports of DC by country: 1987 - 1990, (metric tonnes)

\begin{tabular}{|l|r|r|r|r|}
\hline & 1987 & 1988 & \multicolumn{1}{c|}{1989} & \multicolumn{1}{c|}{1990} \\
\hline Australia & 9,100 & 9,200 & 9,800 & 10,000 \\
Canada & 6,500 & 8,700 & 7,900 & 9,000 \\
France & 6,200 & 6,200 & 6,100 & 6,100 \\
IFR Germany & 14,100 & 9,200 & 11,200 & 13,000 \\
Japan & 2,000 & 2,100 & 3,200 & 4,500 \\
Netherlands & 12,500 & 12,200 & 15,900 & 17,700 \\
U K & 18,900 & 15,900 & 16,600 & 18,700 \\
U S A & 46,000 & 40,800 & 37,600 & 37,100 \\
\hline
\end{tabular}

Source: Table 6 
The United States is the largest single importer of DC, accounting for around 40,000 tonnes per year between 1987 and 1990. Over the last decade there has been a noticeable downward trend for DC imports. Nevertheless, the US market still accounts for over one quarter of world DC trade.

The Philippines supplies around 34,000 tonnes or $85 \%$ of US consumption per year. Strong historical links exist between US purchasers and Philippine manufacturers and this goes some way towards explaining the dominance of this source in the US market. These close links not only simplify procurement, they also afford. a greater degree of quality control and so help to ensure, product uniformity. As a result, the Philippines are almost universally regarded as the preferred source of DC in the US. To the extent that it enters the US market, Sri Lankan and Malaysian material is priced at a significant discount to Philippine supplies. There has been growth in recent years from imports from the Dominican Republic. DC imports from this source supplied over 5,000 tonnes to the US market in 1989 and 1990, which is equivalent to over 10\% of the US DC market.

It is difficult to provide a detailed breakdown of the enduse sectors in the US. However, recent work undertaken at the Natural Resources Institute suggests that one third of total DC supplies are used by the bakery industry, where DC is incorporated into biscuits and doughnuts and also used as a cpating for some bakery items. A similar proportion enters the confectionery industry, where DC use is confined to a relatively small range of products. One quarter probably enters the retail sector, where it is sold largely for home baking. The remaining $10 \%$ or so is used by the food service industry in a range of products including milk shakesand ice creams.

Growth prospects in the US appear - to be limited. The bakery industry is highly competitive and it is therefore difficult to envisage coconut biscuits capturing any significant additional market share. In the confectionery sector, Mars have recently launched their Bounty bar in the US market. However, this may well encroach on the market share of other DC confectionery rather than expand the market base. The retail sector appears to be in a state of long term decline, reflecting the gradual erosion of home-baking.

\section{Western Europe}

Imports of DC to the Europeart Economi Community have averaged over 60,000 tonnes per year between 1987 and 1990, making it the largest regional market (see Table 5, attached). The main exporter to Europe is Sri Lanka, which supplies around $40 \%$ of the European market $(24,000$ tonnes p.a.). The Philippines is the second largest exporter to the EC market, supplying an average 19,000 tonnes of DC per year, or 30\% of total European imports. Ivory Coast supplies around 7,000 tonnes per year, while Malaysia and Indonesia together provide about 5,000 tonnes. The principal markets within Europe are the UK, Netherlands and Germany.

The United Kingdom is the second largest national market for DC after the USA. Although imports have shown erratic year on year changes ranging between 15,000 tonnes and 20,000 tonnes per year, they indicate a slowly declining trend overall. Fifteen years ago, Sri Lanka supplied virtually the whole UK market. Its dominant position has been steadily eroded to the point where it currently supplies less than half. The Philippines has been the main beneficiary of this change and now supplies around one third of the market, while the Cote d'lvoire and Malaysia have also gained a footing in the UK market during the past decade.

These developments can be expiained in part by the impact of industry structure in producing countries. A major problern for users in the UK is mixed mill consignments and the accompanying variation in quality characteristics. A second problem is deterioration in quality resulting from lengthy stock holding at origin. The need for brokers to bulk up output from a large number of small mills makes these problems unavoidable for a large proportion of Sri Lankan 
exports. This has made them vulnerable to competition from the Philippines, which has been able to offer large regular shipments from single mills.

In its favour, Sri Lanka DC flavour is often noted as superior. The problem is that many users are not so much concerned about taste as they are about other functional properties. DC is frequently incorporated into product recipes to impart texture or as a source of fat. For these end users, Sri Lankan supplies hold no inherent advantage because of taste, and Sri Lankan DC must compete with other suppliers in terms of price. It is difficult to assess what proportion of end-users do regard flavour as important. Some users appear to downplay the significance of taste in order to obtain greater leverage in terms of apparen't flexibility of purchasing options between differing origins.

The pattern of usage in the UK appears to differ from that in the US. The bakery inclustry in the UK probably, accounts for almost one half of total usage. Although some companies expect sales of items containing DC to increase, this will probably be at the expense of, competitors' market share and so will have little net effect on the overall demand from this sector. Competition from imported products could even lead to some fall in dernand.

The other major end use sector in the, UK is the confectionery industry. It appears that the introduction of new products and improved export sales of traditional lines containing DC will increase dernand in the short to medium term. Against this must be set the possibility that greater health consciousness may lead to an overall reduction in confectionery consumption in the longer term.

The retail sector in the UK accounts for a much smaller proportion of total usage than in the US. It is difficult to judge market trends since activities such as own labelling by supermarket chains have altered retail market shares in recent years. However, indications are that the sector as a whole is declining.

Overall, the prospects for DC clemand in the UK appear to be finely balanced. In the largest end-use sector, the bakery inclustry, usage is expected to remain at current levels, but may fall if competition from imported iterns intensifies. The confectionery inclustry appears to offer the best prospects for growth, but this may be partially offset by falls in the retail end-use sector. As a result total market clemand may only grow slowly in the UK.

Opportunities for increased usage elsewhere in western Europe appear limited. French imports increased steadily throughout the 1980s from about 4,000 tonnes per year in the period $1977 / 80$ to over 6,000 tonnes per year cluring 1987/90. The growth in DC imports reflects higher usage by the bakery inclustry. However, it is widely believed that the French market will. not undergo any further significant expansion. Although new products containing DC continue to be cleveloped, these now tend to replace existing items rather than expand the market. French DC imports have remained steady at around 6,100 tonnes per year over the past four years.

An analysis of the Benelux market is complicated by the location of the Mars International European factory in the Netherlands and the high level of trade in food ingredients and baked goods between Belgium, the Netherlands and northern France. Compelition within the bakery industry for a greater share of the home market or for increased exports to the UK and Germany, may alter the position of individual Benelux companies, but is not expected to increase total DC usage for the region as a whole.

In Germany the outlook is markedly, different in the two halves of the country. In former West Germany, there appear to ben no clear prospects for increased usage, indeed the trend towards more healthy eating may haye an adverse effect orreoconut product consumption. The situation in 
what used to be East Germany, is quite different. There is a large potential demand for both confectimery and baRery products and it seems likely that offiake of DC would-increase significantly were this potential to be realised.

The economic union with West Germany led to speculation that East Germans would soon enjoy a pronounced rise in spending power, which would significantly increase demand for consurner goods and various foodstuffs. However, more recent developments, most notably the extent of unemployment in the former East Germany, suggest that some of the initial projections may have been over optimistic. Nevertheless, for those who remain in employment, the availability of bakery and confectionery products containing DC has been considerably increased in Eastern Germany through the expansion of West German supermarket chains into the former territory.

A similar situation exists in other areas of eastern Europe. Current offtake is very small in comparison with western Europe and it seems certain that demand for additional supplies exists in Poland, Hungary, Czechoslovakia and Yugoslavia. However, problems with the domestic econornies of these countries limit the availability of foreign exchange for food ingredient imports. Although one can envisage improvements in the medium term in former East Germany, the problems faced by these other eastern-bloc nations are more acute. It therefore seems unlikely that the demand for DC in these countries will be translated into rapidly increased offtake for at least a few years.

\section{Summary and conclusions}

The DC market as a whole has shown a static level of demand in recent years. this contrasts with the recent pattern of supply where competition for market share has intensified as new producers such as Malaysia have become established. Even though existing production capacity exceeds demdrid, there are indications that it is continuing to expand. If existing and currently planned DC capacity are brought into full use without closures elsewhere, then downward pressure on prices seems very probable.

DC prices have shown a substantial fall since their peaks in tfie mid-1980s. Chart 3 shows DC price trends in both current and constant terms (i.e. allowing for the effects of inflation) over the last decade. Chart 4 shown monthly DC prices since 1984. Real, DC prices have, halved since the mid 1980s, and are now at around US\$96q/ton.

There are also wider issues relating to the chan attern of demand for foodstuffs in general. Consurners aie increasi y concerned about food contarnination and additives. In addition, the levels of saturated fats and sugar in the diet have become issues of great importance. Coconut products in particular have fared badly from association with high levels of saturated fat. These issues have to be addressed by the food processing industries, which in turn make ever more stringent demands on commodity producers and exporters.

\section{Prospects for expanding the market}

Against a background of static demand for DC, the prospect of increasing supply and increasingly quality conscious consumers, the prospects for expanding the market do not look strong. However, there are some areas where improvernents can be made. These areas are research and development, promotion, changing market strategies and new product development.

Research and Development offers possibilities in the areas of process design and packing. There are longer term benefits to be gained from developments aimed at improving the bacteriological quality of the DC product. Similarly, improvements in the design of export packs could increase the tonnage carried per container. 
Consurner attitudes to DC could also be researched. Market surveys have shown that consurners either strongly like or dislike the taste of coconut. However, no serious study has been undertaken of the factors that lie behind these results. Such a study may provide information useful to marketing strategies and to guiding new product development.

Promotion has some possibilities. However, it is unlikely that generic promotion will be effective for reasons of cost and efficiency. DC itself has a number of negative associations with saturated fat content, high sugar products and bacteriological integrity. Under these circumstances product specific promotion is likely to be more effective.

Marketing strategies could emphasise product specific promotion, as there are potential gains to be made in increasing DC consumption if known products are launched in new markets. For example, existing confectionery products from Europe and the US could be promoted in new markets such as Eastern Europe, particularly former East Germany. There are, also possibilities for product promotiori in Southern Europe, North Africa and the Middle East.

The Middle Eastern market is already an established demand centre for law-grade Malaysian and Sri Lankan produce. Part of the regional demand reflects a signifficant migrant worker component.

The East Asian market offers prospects for, growth. Japanese imports of DC have risen steadily from around 1,800 tonnes per year in 1985 to around 4,500 tonnes in 1990. Similar growth might also be possible in other economies in the region. However, the growth potential in those countries which actually produce coconuts will be more limited because of consumer preference for fresh coconut products as opposed to DC.

Another aspect of marketing that could be examined further is that new product developments in the European market could be taken to the US, where product development has been less imaginative.

New product development offers other opportunities for expanding the market for DC. A general aspect of product development to date is that DC uses in the major importing countries are largely confined to sweet products. Coconut usage in producing countries cover both sweet and savoury products. There, may therefore be potential in developing a range of savoury uses for DC in the importing markets.

In addition, there has been a trend towards transferring established confectionery items to ice-cream and other products. The launch of the "Bounty" ice-cream has been successful in stimulating demand for DC. Other options in this area could include: products containing both DC and coconut crearn or milk; upmarket confectionery and bakery items and more research into ice-creams, yoghurts and other cooled or frozen items. However, such developments will take place against a background of growing consurner awareness of dietary health issues, arid of potential. resistance to the consumption of sweet items. 
Table 5 Exports of Desiccated coconut - major producers 1976-1990 (metric tons)

\begin{tabular}{|c|c|c|c|c|c|c|c|c|c|c|c|c|c|c|c|c|}
\hline Year & 1975 & 1976 & 1977 & 1978 & 1979 & 1980 & 1981 & 1982 & 1983 & 1984 & 1985 & 1986 & 1987 & 1988 & 1989 & 1990 \\
\hline Philippines & 66,280 & 81,355 & 98,563 & 91,498 & 83,396 & 87,860 & 87,725 & 89,182 & 89,362 & 64,752 & 67,893 & 95,154 & 88,412 & 93,732 & 74,863 & 74,863 \\
\hline Sri Lanka & 59,307 & 45,988 & 30,327 & 41,591 & 41,591 & 31,860 & 40,685 & 42,096 & 42,135 & 52,985 & 59,811 & 53,232 & 22,422 & 43,205 & 50,543 & 50,543 \\
\hline Malaysia & & & 118 & 324 & 829 & 1,741 & 5,443 & 2,105 & 3,517 & 8,193 & 7,209 & 13,216 & 26,268 & 17,877 & 18,000 & 18,000 \\
\hline Indonesia & & & 1,490 & 284 & 1,498 & 1,013 & 45 & 2,148 & 1,608 & 5,831 & 303 & 2,440 & 3,812 & 501 & 2,774 & 2,774 \\
\hline Ivory Coast & & & 91 & 0 & 0 & 0 & 3,832 & 3,488 & 3,845 & 6,493 & 7,200 & 6,500 & 6,124 & 6,897 & 6,580 & 6,580 \\
\hline $\begin{array}{l}\text { Total main } \\
\text { producer }\end{array}$ & 125,587 & 127,343 & 130,589 & 133,697 & 125,698 & 122,474 & 137,730 & 139,019 & 140,467 & 122,073 & 138,164 & 142,416 & 170,542 & 147,038 & 162,212 & 152,760 \\
\hline
\end{tabular}

Notes: Malaysia 1990 est.; 1989 \& 1988 national trade statistics:

Ivory Coast 1988-90; exports to France, Netherlands and UK only

Source: FAO Trade yearbook-various issues

Eurostat 1990

National Trade Statistics

Food news-1990 figures

Cocomunity-Indonesia 1988-90 export figures

Gill \& Duffus-Edible Nut Statistics, export figures between 1975 and 1988

Average exports over a three year period

\begin{tabular}{lrrr} 
& $1968 / 70$ & $1978 / 80$ & $1988 / 90$ \\
\hline----------------- \\
Philippines & 67,024 & 87,585 & 85,669 \\
Sri Lanka & 57,021 & 37,809 & 38,723 \\
Malaysia & $*$ & 965 & 20,715 \\
Indonesia & $*$ & 932 & 2,362 \\
Ivory Coast & 647 & 0 & 6,534 \\
\hline Total & 119,692 & 127,290 & 154,003
\end{tabular}

Note: ${ }^{*}=$ not significant

Exports by Destination

$\begin{array}{lrr}\text { Philippines } & 1989 & 1990 \\ \text { USA } & 38578 & 34054 \\ \text { Australia } & 9167 & 7664 \\ \text { Netherlands } & 9445 & 6998 \\ \text { Canada } & 4991 & 5618 \\ \text { UK } & 6713 & 4880 \\ \text { Germany } & 9044 & 3028 \\ \text { Taiwan } & 1481 & 1917 \\ \text { Japan } & 1198 & 1509 \\ \text { Sweden } & 1432 & 1168 \\ \text { Belgium/Lux } & 587 & 1010 \\ \text { Others } & 11096 & 6837 \\ \text { Total } & 92732 & 74683\end{array}$

Source: United Coconut Assn of Philippines

$\begin{array}{lll}\text { EEC } & 25899 & 15916 \\ \text { non EEC/USA } & 29365 & 24713\end{array}$


Table 6 Imports of Desiccated coconut-major consumers 1976-1990 (metric tons)

\begin{tabular}{|c|c|c|c|c|c|c|c|c|c|c|c|c|c|c|c|c|}
\hline Year & 1975 & 1976 & 1977 & 1978 & 1979 & 1980 & 1981 & 1982 & 1983 & 1984 & 1985 & 1986 & 1987 & 1988 & 1989 & 1990 \\
\hline USA & 40374 & 43841 & 43008 & 45918 & 39649 & 39444 & 39526 & 40217 & 43454 & 36501 & 43579 & 36462 & 46007 & 40824 & 37584 & 37139 \\
\hline UK & 14549 & 15483 & 17577 & 17601 & 19114 & 15143 & 15986 & 15631 & 20145 & 18472 & 15283 & 17167 & 15947 & 15947 & 16577 & 18659 \\
\hline Netherlands & & 7190 & 7614 & 7621 & 7490 & 7874 & 7263 & 9007 & 9940 & 8103 & 10147 & 11284 & 12246 & 12246 & 15948 & 17681 \\
\hline Germany & 8450 & 8552 & 9575 & 9450 & 9891 & 8737 & 10154 & 9502 & 9279 & 9978 & 10663 & 10776 & 9197 & 9197 & 11201 & 13024 \\
\hline Canada & 4386 & 5352 & 5194 & 6158 & 5815 & 5130 & 5474 & 5192 & 5889 & 5739 & 6449 & 6192 & 8735 & 8735 & 7894 & 8980 \\
\hline Australia & 6000 & 6100 & 5586 & 6924 & 5964 & & & & 6897 & 8202 & 8869 & 8644 & 9239 & 9239 & 9840 & 9956 \\
\hline France & 3618 & 3026 & 3985 & 4467 & 4112 & 4694 & 4794 & 4858 & 5633 & 5061 & 5132 & 5386 & 6183 & 6183 & 6135 & 6114 \\
\hline Japan & 1668 & 2557 & 2580 & 2201 & 2263 & & & & 1763 & 1672 & 1836 & 1673 & 2143 & 2143 & 3228 & 4523 \\
\hline Total & 79045 & 92101 & 95119 & 100340 & 94229 & 81022 & 83197 & 84407 & 10300 & 93728 & 101958 & 97584 & 104514 & 104514 & 108407 & 116076 \\
\hline
\end{tabular}

Notes:

Average imports ove a four year period

Source: FAO Trade Yearbook-Australia (1987-89), Japan 1987

Eurostat: EC-12 imports

National Trade Statistics-Australia 1990

Food news-1990 figures

Gill \& Duffus-Edible Nut Statistics, until 1988

$\begin{array}{lrr} & 1977 / 80 & 1987 / 90 \\ \text { USA } & 42,005 & 40,389 \\ \text { UK } & 17,359 & 17,529 \\ \text { Netherlands } & 7,650 & 14,590 \\ \text { Germany } & 9,413 & 11,886 \\ \text { Canada } & 5,574 & 8,039 \\ \text { Australia } & 6,158 & 9,541 \\ \text { France } & 4,315 & 6,159 \\ \text { Japan } & 2,348 & 2,962\end{array}$

Breakdown of Import Sources for USA and EC-12

\begin{tabular}{|c|c|c|c|c|c|c|c|c|c|c|c|c|c|}
\hline USA & 1987 & 1988 & 1989 & 1990 & $\begin{array}{c}4 y r \\
\text { Average }\end{array}$ & $\begin{array}{l}\% \text { of } \\
\text { total }\end{array}$ & USA & 1987 & 1988 & 1989 & 1990 & $\begin{array}{c}4 y r \\
\text { average }\end{array}$ & $\begin{array}{l}\% \text { of } \\
\text { total }\end{array}$ \\
\hline $\begin{array}{l}\text { DC Imports } \\
\text { of which from: }\end{array}$ & 46007 & 40824 & 37584 & 37139 & 34,463 & & $\begin{array}{l}\text { DC Imports } \\
\text { of which from: }\end{array}$ & 65437 & 54469 & 61458 & 59681 & 60,261 & \\
\hline Philippines & 40899 & 38218 & 29825 & 28098 & 34,463 & $85 \%$ & Sri Lanka & 29720 & 15132 & 22783 & 29347 & 24,246 & $40 \%$ \\
\hline Dominica Rep. & & 356 & 6167 & 5882 & 4,135 & $10 \%$ & Philippines & 18570 & 19612 & 22140 & 17375 & 19,424 & $32 \%$ \\
\hline Malaysia & 124 & 1248 & 730 & 546 & 662 & $2 \%$ & Ivory Coast & 6999 & 6532 & 7438 & 7139 & 7,027 & $12 \%$ \\
\hline Sri Lanka & 2667 & 273 & & & 1,470 & $4 \%$ & Others & 10148 & 13193 & 9097 & 5820 & 9,565 & $16 \%$ \\
\hline Others & 2317 & 729 & 862 & 1803 & 1,428 & $4 \%$ & & & & & & & \\
\hline Total & 46007 & 40824 & 37484 & 37139 & 40,389 & & Total & 65437 & 54469 & 61458 & 59681 & 60,261 & \\
\hline
\end{tabular}



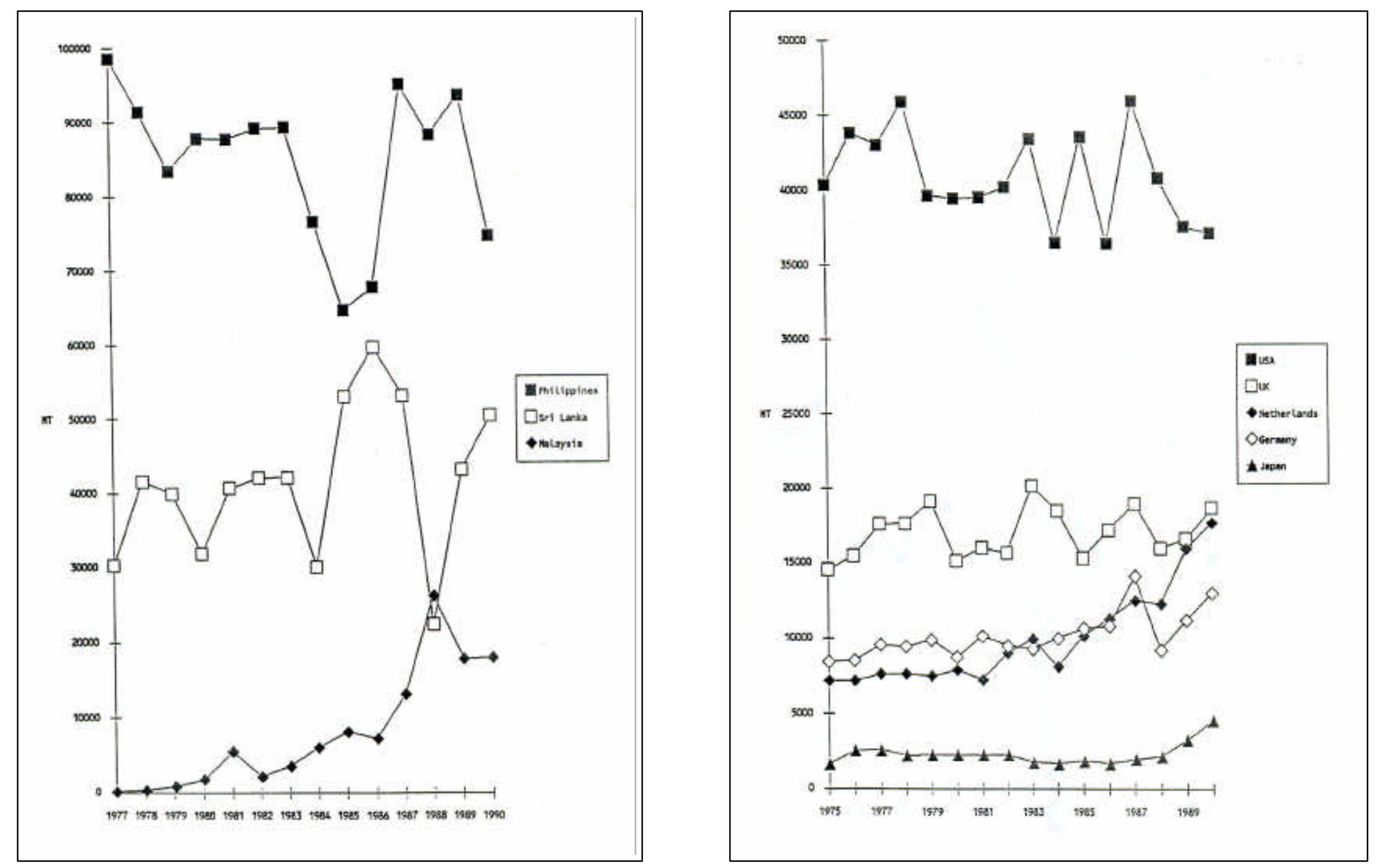

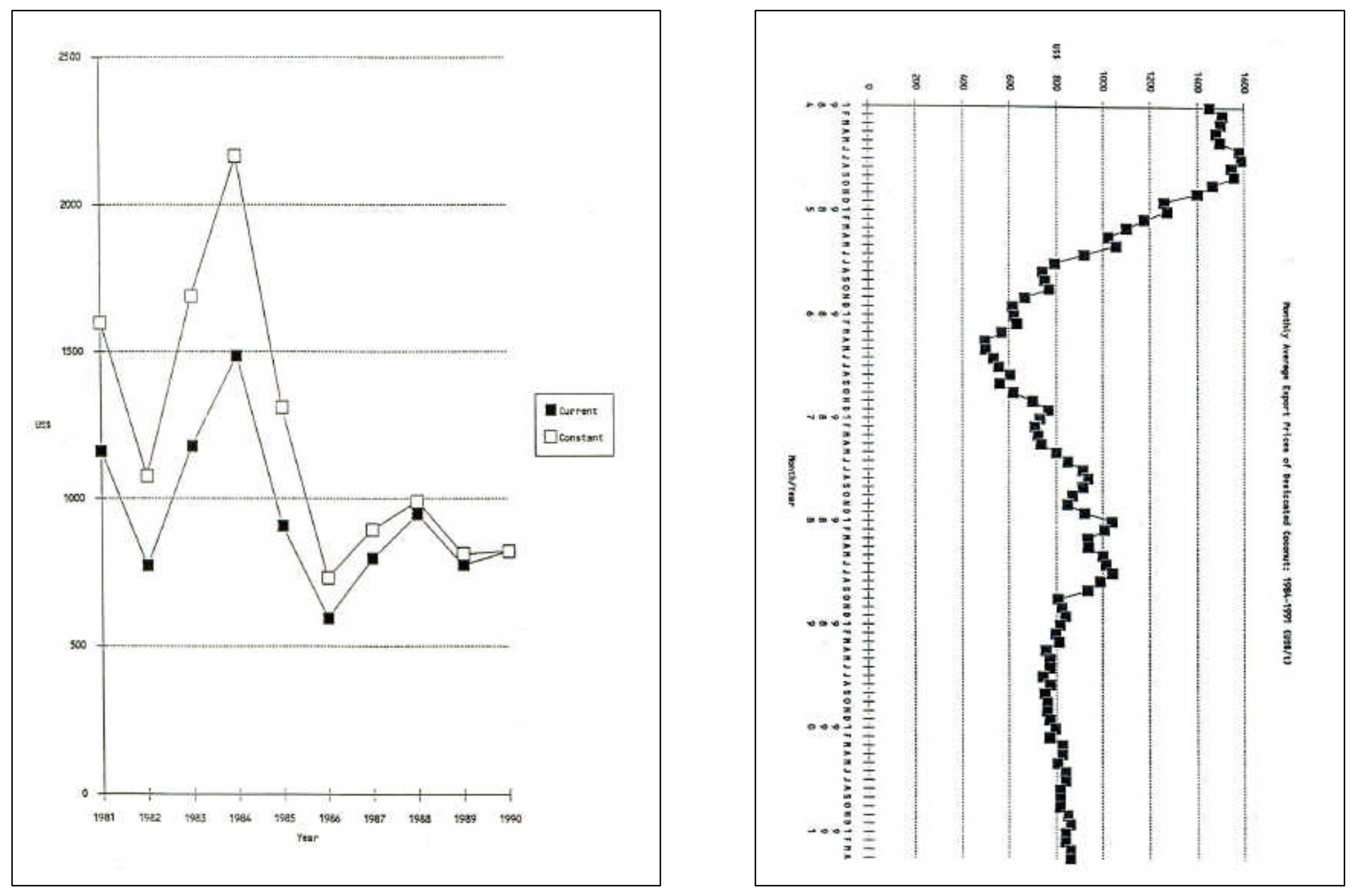